\title{
EVALUASI TINGKAT KUALITAS PELAYANAN BIDANG KEMAHASISWAAN MENGGUNAKAN SERVEQUAL DI POLITEKNIK NEGERI JAKARTA
}

\author{
Fatimah $^{1)}$, Darna ${ }^{2)}$ dan Ansori ${ }^{3)}$ \\ 1,2,3 Jurusan Akuntansi Politeknik Negeri Jakarta \\ Email : ${ }^{1}$ fatimah@akuntansi.pnj.ac.id , ${ }^{2}$ darna@akuntansi.pnj.ac.id , ${ }^{3}$ ansori@akuntansi.pnj.ac.id
}

\begin{abstract}
Abstrak
Penelitian ini bertujuan mengevaluasi tentang pelayanan kemahasiswaan di Politeknik Negeri Jakarta (PNJ), sehingga dengan evaluasi ini diharapkan memperoleh masukan untuk peningkatan kualitas pelayanan (service quality) kemahasiswaan. Metode yang digunakan adalah metode Servqual yang membandingkan antara layanan yang dirasakan (adequate service) dan layanan yang diharapkan (desired service) oleh mahasiswa. Teknik sampel yang digunakan non random sampling yaitu melalui pendekatan accidental sampling. Alasan memilih metode ini karena peneliti menganggap bahwa mahasiswa politeknik adalah homogen. Hasilnya adalah sebagai berikut: 1) dari hasil uji service quality (Servequal) setiap item dimensi tangible, reliability, responsiveness, assurance, emphaty dan system information terdapat gap negatif antara yang dirasakan dengan yang diharapan oleh mahasiswa; 2) a) pada aspek tangible yang terdiri atas sarana prasarana pendidikan, peralatan laboratorium dan ruang perkuliahan diperoleh gap servequal yang negative -1.4; b) aspek reliability yang terdiri atas keandalan dosen dan staf akademik masih memiliki gap sebesar - 1.01; c) aspek responsiveness atau sikap tanggap dalam pelayanan kepada mahasiswa diperoleh gap sebesar -1.19; d) aspek assurance atau perlakuan terhadap mahasiswa diperoleh gap sebesar -1.12 ; e) aspek empathy atau pemahaman terhadap kepentingan mahasiswa memiliki gap -1.21; dan f) aspek system informasi kemahasiswaan memperoleh gap -1.27; 3) Secara keseluruhan tingkat kepuasan mahasiswa terhadap layanan bidang akademik dan kemahasiswaan menghasilkan gap sebesar -1.19. Ini menunjukkan bahwa Politeknik Negeri Jakarta masih harus meningkatkan kualitas pelayanannya pada semua dimensinya.
\end{abstract}

Kata kunci: evaluasi, kualitas layanan, kepuasan, harapan dan persepsi

\section{PENDAHULUAN}

Salah satu tolok ukur keberhasilan sebuah lembaga pendidikan adalah diukur dari jumlah pendaftar atau jumlah mahasiswa yang ada pada lembaga tersebut. Semakin baik citra (image) suatu institusi pendidikan dimata masayarakat baik pada skala nasional ataupun internasional akan memberikan dampak positif dengan meningkatnya jumlah pendaftar untuk mengenyam pendidikan di institusi tersebut. Industri pendidikan merupakan bagian dari sektor jasa dimana pada sektor ini promosi yang paling efektif adalah adalah rekomendasi dari pengguna jasa atas kepuasan dari layanan yang diterima pada saat bertransaksi maupun layanan setelah transaksi dilakukan. Pelanggan pada institusi pendidikan tinggi yang tidak lain adalah mahasiswa, memiliki keunikan tersendiri dibandingkan pelanggan pada industri jasa lainnya. Perbedaan yang terlihat nyata adalah keterikatan pelanggan dalam suatu periode waktu tertentu yang cukup lama.

Mahasiswa cenderung akan mengikuti aturan yang ditetapkan oleh institusi tanpa dapat melakukan negosiasi atau tawar- 
menawar. Ketidakpuasan atas layanan yang diberikan tidak dapat direspon secara mudah dan cepat dengan berpindah pada lembaga pendidikan lainnya. Berbeda dengan industri perbankan, asuransi, rumah sakit dan lain sebagainya. Untuk itu, respon yang dapat dilakukan adalah dengan tidak merekomendasikan kerabat atau orang disekitar lingkungannya untuk masuk ke institusi pendidikan tersebut. Kekecewaan pelanggan tetap akan direspon, namun bentuk dari respon berbeda antara industri jasa non pendidikan dengan jasa bidang pendidikan. Begitupula sebaliknya, pengalaman yang baik yang diterima oleh mahasiswa dapat menimbulkan kepuasan yang akan bernilai positif bagi institusi. Informasi dari mulut ke mulut (mouth to mouth promotion) untuk merekomendasikan kerabat ataupun teman dekat, menunjukkan bahwa institusi memberikan kepuasan pelanggan yang tinggi.

Politeknik Negeri Jakarta (PNJ) sebagai institusi pendidikan tinggi yang menawarkan jasa dibidang pendidikan, sejauh ini belum memberikan pelayanan yang terbaik atau belum memberikan pelayanan optimal kepada para mahasiswanya. Hal ini dapat dilihat dari masih banyaknya keluhan mahasiswa kepada para dosennya mulai dari sarana dan prasarana yang diterimanya maupun tentang dosen yang mengampu matakuliah di kelas. Selain itu, yang menjadi masalah berikutnya adalah masih banyaknya mahasiswa PNJ yang pada tahun kedua pindah ke universitas negeri atau meninggalkan PNJ karena merasa tidak puas. Oleh karena itu yang menjadi pertanyaan penelitian adalah: "Bagaimanakah tingkat kepuasan mahasiswa tentang kualitas pelayanan bidang akademik dan kemahasiswaan di Politeknik Negeri Jakarta”.

Tujuan penelitian ini adalah untuk melakukan evaluasi agar hasilnya menjadi masukan bagi PNJ sebagai institusi pendidikan, untuk senantiasa terus melakukan perbaikan dan meningkatkan terus kualitas pelayanannya kepada mahasiswa.

Pengguna jasa pendidikan dalam hal ini adalah mahasiswa harus tetap mendapatkan kepuasaan yang maksimal. Menurut (Reina, Mei 2012), proses perkuliahan akan terlaksana dengan baik apabila terjaminnya kualitas dosen, terjalinnya komunikasi yang lancar antara dosen dengan mahasiswa dan orang tua mahasiswa, adanya bimbingan konseling bagi mahasiswa yang bermasalah, serta kelengkapan prasarana merupakan beberapa faktor yang memberikan tingkat kepuasan kepada mahasiswa. Pada penelitian lain dikatakan bahwa rendahnya kepuasan mahasiswa karena fasilitas yang disediakan oleh Institusi belum sesuai dengan biaya kuliah yang telah dibayar oleh mahasiswa walaupun kualitas dosen sudah mencukupi (Sutrisno, 2017).

Kepuasan atau ketidakpuasan adalah perasaan senang atau kecewa seseorang yang berasal dari perbandingan antara kesan terhadap kinerja yang riil atau aktual dengan kinerja yang diharapkan. Menurut (Zeithaml, 2005), kepuasan konsumen merupakan “customer's evaluation of a product or service in terms of whether that product or service has met their needs and expectation". Konsumen yang merasa puas terhadap produk ataupun jasa yang dibeli dan digunakannya akan kembali menggunakan jasa atau produk yang ditawarkan tersebut. Hal ini akan membangun kesetiaan konsumen (Sopiah, 2013). Sedangkan menurut (Kotler, 2005) kepuasan adalah sejauh mana suatu tingkatan produk dipersepsikan sesuai dengan harapan pembeli. Kepuasan konsumen diukur dengan seberapa besar harapan konsumen tentang produk atau jasa sesuai dengan kenyataan yang diterima oleh konsumen. Kepuasan konsumen adalah perasaan senang atau kecewa yang muncul setelah membandingkan persepsi atau kesan 
dengan kinerja suatu produk dan harapanharapannya. Jika produk atau jasa tersebut jauh dibawah harapan, konsumen akan kecewa. Sebaliknya, jika produk atau jasa tersebut memenuhi harapan, maka konsumen akan puas.

Menurut (Schnaars, 1991) pada dasarnya tujuan dari suatu bisnis adalah untuk menciptakan para pelanggan merasa puas. Terciptanya kepuasan pelanggan dapat memberikan beberapa manfaat, diantaranya hubungan antara perusahaan dan pelanggannya menjadi harmonis, memberikan dasar yang baik bagi pembelian ulang dan terciptanya loyalitas pelanggan dan membentuk suatu suatu rekonendasi dari mulut ke mulut (word of mouth) yang menguntungkan bagi perusahaan (Tjiptono, 1994). Ada beberapa pakar yang memberikan definisi mengenai kepuasan atau ketidakpuasan pelanggan. Day dalam bukunya menyatakan bahwa kepuasan atau ketidakpuasan adalah respon pelanggan terhadap evaluasi ketidaksesuaian (disconfirmation) yang dirasakan antara harapan sebelumnya (atau norma kinerja lainnya) dan kinerja aktual produk/jasa yang dirasakan setelah mengkonsumsinya. Dalam bukunya (Engel at. al, 1990) menyatakan bahwa kepuasan pelanggan merupakan evaluasi purnabeli dimana alternatif yang dipilih sekurang-kurangnya sama atau melampaui harapan pelanggan. Sedangkan ketidakpuasan timbul apabila hasil (outcome) tidak memenuhi harapan.

Persaingan yang semakin ketat, dimana semakin banyak perguruan tinggi yang terlibat dalam pemenuhan kebutuhan dan keinginan calon peserta didik, menyebabkan setiap perguruan tinggi harus menempatkan orientasi pada kepuasan mahasiswa sebagai tujuan utama. Hal ini tercermin dari semakin banyaknya perguruan tinggi yang mengedepankan komitmennya terhadap pelayanan kepada mahasiswa dalam pernyataan misinya, iklan maupun public relation release. Dewasa ini semakin diyakini bahwa kunci utama untuk memenangkan persaingan adalah memberikan nilai dan kepuasan kepada para peserta didik sebagai pengguna jasa, melalui penyampaian produk dan jasa berkualitas dengan harga bersaing dan terjangkau oleh seluruh lapisan masyarakat.

Semakin banyaknya perguruan tinggi yang menawarkan jasa pendidikannya, maka calon mahasiswa sebagai konsumen memiliki pilihan yang semakin banyak. Dengan demikian kekuatan tawar menawar konsumen pengguna jasa semakin besar. Hak-hak mahasiswa sebagai konsumenpun mulai mendapatkan perhatian besar, terutama aspek jaminan kualitas dalam memilih layanan perguruan tinggi tertentu. Kini mulai banyak bermunculan aktivitas-aktivitas pengguna jasa (konsumeris) yang memperjuangkan hak konsumen, etika bisnis serta kesadaran dan kecintaan terhadap lingkungan. Para peneliti perilaku konsumenpun semakin banyak yang tertarik dan menekuni topik kepuasan pelanggan dalam rangka mengupayakan solusi yang optimal dari pemenuhan kepuasan para pelanggan.

Penelitian yang dilakukan oleh Nidhomuzzaman (2011) terhadap pelayanan jasa di MAN Sidoarjo yang menggunakan pendekatan analisis servqual dan hasilnya diketahui indikator yang harus ditingkatkan kualitas layanannya adalah kecepat-tanggapan pihak manajemen dengan keluhan siswasiswi dengan serqual terbobot -0.16007 , kecepatan tanggapan karyawan dalam memberikan bantuan yang di minta oleh siswa-siswi dengan serqual terbobot 0.10858 , luas area parkir dengan serqual terbobot -0.10281, kesesuaian materi pelajaran yang di ajarkan dengan yang diprogram dengan serqual terbobot 0.08799, ketepatan waktu belajar mengajar dengan jadwal dengan serqual terbobot -0.08084, kecepatan tanggapan pengajaran dalam hal pertanyaan kritikan dan keluhan dari siswa-siswi dengan 
serqual terbobot -0.0748 , desain ruang belajar mengajar dengan serqual terbobot -0.05993, kebersihan dan kenyamanan ruangan belajar mengajar dan fasilitasnya dengan serqual terbobot -0.05545 .

Hal yang hampir serupa adalah penelitian yang dilakukan oleh Baheransyah (2012) dengan mengidentifikasi kualitas pelayanan jasa pendidikan Sekolah Menengah Atas (XYZ) dengan hasil terdapat 12 atribut pelayanan yang harus diperbaiki dari 32 atribut yang di ujikan. Sehingga sekolah tersebut sudah lebih dari setengah pelayanannya yang sudah sesuai dengan harapan siswa SMS XYZ.

Penelitian Hasibuan dkk (2017) yang menggunakan metode Servequal, menyatakan bahwa kualitas pelayanan jasa di Fakultas Teknik Universitas $\mathrm{X}$ belum sepenuhnya memuaskan mahasiswa karena hampir seluruh variabel pelayanan yang dinilai memiliki nilai gap yang negatif. Dengan nilai gap terbesar yakni -0.9186 menunjukkan bahwa fasilitas yang diberikan belum sesuai dengan biaya uang kuliah yang dibayarkan oleh mahasiswa sehingga perlu dilakukan perbaikan terhadap fasilitas utama dan penunjang yang dapat dirasakan oleh mahasiswa teknik untuk memperlancar kegiatan belajar dan mengajar.

Berdasarkan berbagai penjelasan tentang kepuasan di atas dapat disimpulkan bahwa pada dasarnya pengertian kepuasan pelanggan mencakup perbedaan antara harapan dan kinerja atau hasil yang dirasakan. Tingkat kepuasan yang akan diukur dalam penelitian ini terkait dengan: a) reliabilitas layanan (Reliability) yang dilihat dari kualitas proses perkuliahan, kualitas dosen, penyampaian materi pengajaran dan layanan administrasi akademik dan kemahasiswaan; b) kepekaan layanan atau sikap tanggap (Responsiveness), dalam hal ini dilihat dari komunikasi antara dosen dan tenaga kependidikan dengan mahasiswa, bimbingan konseling terhadap mahasiswa yang bermasalah, konsultasi orang tua dan layanan pengobatan gratis serta asuransi bagi mahasiswa; c) Jaminan layanan (Assurance), dalam hal ini adalah bentuk layanan staf administrasi yang santun dan ramah, cepat menangani keluhan mahasiswa, pelayanan oleh dosen dalam proses pengajaran dan bimbingan akademik; d) Empaty (Empathy), dalam hal ini PNJ harus menyediakan bimbingan dan konseling dengan nama (Student Advisory Center) yang dapat menunjang keberhasilan mahasiswa dalam studinya, termasuk penyediaan beasiswa; e) Fasilitas yang berwujud (Tangibles), dalam hal ini terkait dengan ruang kelas yang nyaman, perpustakaan yang mumpuni, internet corner dan hot spot dan fasilitas lain seperti kantin, foto copy, koperasi, bank, ATM dan lahan parker; f) Sistim informasi (information system), dalam hal ini adalah dalam bentuk informasi system perkuliahan, informasi akademik dan non akademik dan pelayanan informasi terkait berbagai hal secara daring (on-line).

\section{METODOLOGI}

Pendekatan penelitan yang digunakan adalah penelitian deskriptif yang bertujuan untuk mengetahui secara spesifik, jelas dan terperinci bagaimana kualitas pelayanan yang diberikan instansi menurut persepsi penerima layanan. Disamping itu, untuk memetakan secara pasti variabel-variabel kualitas pelayanan, maka akan ditempatkan dalam diagram kartesius. Penelitian ini akan difokuskan pada bagaimana kualitas pelayanan kemahasiswaan PNJ dilihat dari dimensi tangible, reliability, responsiveness, assurance, emphaty dan information system. Mengacu pada model tersebut, perlu untuk menyeimbangkan antara harapan dan yang dirasakan penerima layanan serta menutup kesenjangan antara harapan dan yang dirasakan merupakan kunci kualitas pelayanan. 
Adapun instrument servequal akan dibagi menjadi dua, dimana pada bagian pertama merupakan pertanyaan untuk mengukur persepsi penerima layanan terhadap pelayanan dan bagian kedua digunakan untuk pertanyaan pengukur tingkat harapan penerima layanan. Jumlah pertanyaan adalah 41 pertanyaan dan mencakup tentang enam dimensi kualitas pelayanan. Selanjutnya untuk menghitung perbedaan tersebut digunakan formula:

\section{Skor Servqual $=$ Skor Persepsi - Skor Harapan}

Penelitian tentang evaluasi pelayanan kemahasiswaan akan dilaksanakan di Politeknik Negeri Jakarta (PNJ). Pemilihan lokasi ini didasarkan pada pertimbangan sebagai berikut: 1) ingin mengetahui response mahasiswa Politeknik Negeri Jakarta terkait dengan layanan yang diberikan; 2) karena skim pendanaan penelitian ini bertujuan untuk pengembangan institusi; 3) hasil dari penelitian ini dapat dijadikan masukan bagi pengambil keputusan di PNJ. Sedangkan pengumpulan data penelitian melalui survey kepada mahasiswa politeknik dilakukan mulai bulan Mei sampai dengan Oktober 2018.

Populasi penelitian adalah seluruh mahasiswa PNJ yang terdiri dari tujuh (7) jurusan. Jumlah populasi mahasiswa dari tujuh jurusan adalah sebanyak 2.163 orang mahasiswa. Teknik sampel yang digunakan non random sampling yaitu melalui pendekatan accidental sampling. Alasan memilih metode ini karena peneliti menganggap bahwa mahasiswa politeknik adalah homogen. Penentuan jumlah sampel (sample size) menggunakan purposive sampling, dalam hal ini peneliti menentukan sebanyak 100 orang mahasiswa semester tiga ke atas dari berbagai jurusan yang ada di PNJ.

Jenis data penelitian ini adalah data kualitatif. Sedangkan berdasarkan tingkat pengukurannya termasuk dalam kategori data ordinal yaitu data yang tidak memiliki nilai kuantitas yang dapat menunjukan perbedaan tingakatan satu hal dengan hal lainnya. Untuk pengukuran data yang digunakan dalam penelitian ini adalah skala likert. Skala likert merupakan jenis skala yang digunakan untuk mengukur variabel penelitian (fenomena sosial spesifik), seperti sikap, pendapat dan persepsi seseorang atau sekelompok orang. Variabel penelitian yang diukur dengan skala likert ini, dijabarkan menjadi indikator variabel yang kemudian dijadikan titik tolak penyusunan butir-butir instrumen. Instrumen penelitian yang menggunakan skala likert dapat dibuat dalam bentuk multiple choice atau checklist.

Untuk mengumpulkan data serta informasi yang diperlukan oleh penulis menggunakan metode sebagai berikut:

a. Daftar Pertanyaan (questioner)

Teknik pengumpulan data dengan jalan melakukan pembagian daftar pertanyaan langsung kepada responden yang menjadi objek penelitian, sehingga data yang penulis kumpulkan benar-benar sesuai dengan keadaan yang sebenarnya pada saat penelitian berlangsung.

b. Wawancara (interview)

Pengumpulan data dengan cara mengadakan tanya jawab langsung kepada pihak-pihak terkait di PNJ yang dianggap dapat memberikan penjelasan langsung ataupun memberikan data sebagai pelengkap penulisan ini.

Metode analisa data yang diperoleh melalui metode SERVQUAL, selanjutnya dicari score gap antara kualitas layanan yang dirasakan $(\mathrm{P})$ dengan harapan yang diinginkan (E) secara terinci sebagai berikut: a) Analisa gap untuk item per item pertanyaan dengan rumus P1 - E1 (Persepsi item 1 - Ekspektasi item 1), P2 - E2 (Persepsi item 2 - Ekspektasi item 2 ) dan seterusnya untuk semua item pertanyaan; b) Analisa gap untuk dimensi per dimensi dengan cara menjumlahkan angka dari setiap pertanyaan dibagi dengan banyaknya pertanyaan pada setiap dimensi sebagai berikut: 
$((\mathrm{P} 1+\mathrm{P} 2+\mathrm{P} 3+\mathrm{P} 4+\ldots+\mathrm{Pn}) / \mathrm{n} \quad-$ $(\mathrm{E} 1+\mathrm{E} 1+\mathrm{E} 3+\mathrm{E} 4+\ldots+\mathrm{En}) / \mathrm{n})$ dimana $\mathrm{n}$ adalah banyaknya pertanyaan pada setiap dimensi; c) Analisa gap antara pelayanan yang dirasakan dengan yang diharapkan secara keseluruhan untuk semua dimensi pelayanan dengan cara menjumlahkan seluruh item pertanyaan apa yang dirasakan dikurangi hasil penjumlahan dari seluruh item pertanyaan tentang ekspektasi sebagai berikut: $((\mathrm{P} 1+\mathrm{P} 2+\mathrm{P} 3+\mathrm{P} 4+\ldots .+\mathrm{Pk}) / \mathrm{k} \quad-$ $(\mathrm{E} 1+\mathrm{E} 2+\mathrm{E} 3+\mathrm{E} 4+\ldots . .+\mathrm{Ek}) / \mathrm{k})$ dimana $\mathrm{k}$ adalah total seluruh item pertanyaan pada kuesioner.

\section{HASIL DAN PEMBAHASAN}

Setelah dilakukan tabulasi data kuesioner dan dibuat rekapitulasi data persepsi dan harapan responden tentang kualitas pelayanan di PNJ, maka dapat dilakukan perhitungan nilai rata-rata persepsi responden, nilai rata-rata harapan responden dan gap antara persepsi dengan harapan yang diinginkan sebagai berikut:

Tabel 1: Gap antara persepsi dan harapan pada dimensi Tangible

\begin{tabular}{|c|c|c|c|c|}
\hline $\begin{array}{l}\mathrm{N} \\
\mathrm{o}\end{array}$ & $\begin{array}{l}\text { Aspek sarana prasarana } \\
\text { pendidikan, peralatan dan } \\
\text { media pengajaran }\end{array}$ & $\begin{array}{l}\text { Persepsi } \\
\text { (P) }\end{array}$ & $\begin{array}{l}\text { Harapan } \\
\text { (E) }\end{array}$ & $\begin{array}{l}\text { Gap } \\
\text { (P-E) }\end{array}$ \\
\hline 1 & $\begin{array}{l}\text { Ruang kuliah tertata rapih } \\
\text { dan bersih }\end{array}$ & 3.32 & 4.45 & -1.22 \\
\hline 2 & $\begin{array}{l}\text { Ruang kuliah sejuk dan } \\
\text { nyaman }\end{array}$ & 3.09 & 4.55 & -1.45 \\
\hline 3 & $\begin{array}{l}\text { Sarana di ruang kuliah } \\
\text { tersedia lengkap }\end{array}$ & 3.38 & 4.55 & -1.17 \\
\hline 4 & $\begin{array}{l}\text { Perpustakaan dimiliki } \\
\text { PNJ sangat lengkap }\end{array}$ & 2.77 & 4.33 & -1.56 \\
\hline 5 & $\begin{array}{lr}\text { Laboratorium dan } & \text { dan } \\
\text { bengkel sudah } & \text { relevan } \\
\text { dengan } & \text { keilmuan } \\
\text { mahasiswa } & \end{array}$ & 3.42 & 4.55 & -1.13 \\
\hline 6 & $\begin{array}{l}\text { Ketersediaan buku dan } \\
\text { sumber referensi lainnya } \\
\text { di perpustakaan sudah } \\
\text { memadai }\end{array}$ & 2.81 & 4.41 & -1.59 \\
\hline 7 & $\begin{array}{l}\text { Ketersediaan fasilitas } \\
\text { kamar kecil jumlahnya } \\
\text { cukup bersih dan terawat }\end{array}$ & 2.84 & 4.52 & -1.63 \\
\hline 8 & $\begin{array}{l}\text { Fasilitas tempat ibadah } \\
\text { sudah memadai }\end{array}$ & 3.05 & 4.48 & -1.44 \\
\hline \multicolumn{2}{|r|}{ Gap untuk dimensi tangible } & 3.08 & 4.48 & -1.44 \\
\hline
\end{tabular}

Berdasarkan tabel 1 tersebut tampak bahwa semua item dalam dimensi tangible menunjukkan angka yang negative, dimana gap yang terendah -1.13 terdapat pada fasilitas laboratorium dan bengkel, dan gap tertinggi terjadi pada ketersedian fasilitas kamar kecil yang bersih yaitu -1.63. Secara keseluruhan dimensi tangible memiliki gap yang negative sebesar -1.44, ini berarti apa yang dirasakan mahasiswa terkait dengan sarana prasarana pendidikan dan media pengajaran masih lebih rendah dari yang mereka harapkan.

Tabel 2: Gap antara persepsi dan harapan pada dimensi Reliability (keandalan)

\begin{tabular}{|c|c|c|c|c|}
\hline $\begin{array}{l}\mathrm{N} \\
\mathrm{O}\end{array}$ & $\begin{array}{l}\text { Aspek keandalan dosen } \\
\text { dan staf akademik }\end{array}$ & $\begin{array}{l}\text { Persepsi } \\
\text { (P) }\end{array}$ & $\begin{array}{l}\text { Harapan } \\
\text { (E) }\end{array}$ & $\begin{array}{l}\text { Gap } \\
\text { (P-E) }\end{array}$ \\
\hline 1 & $\begin{array}{l}\text { Materi perkuliahan dari } \\
\text { para dosen diberikan/ } \\
\text { disampaikan dengan jelas }\end{array}$ & 3.33 & 4.41 & -1.08 \\
\hline 2 & $\begin{array}{l}\text { Waktu yang disediakan } \\
\text { untuk diskusi dan tanya } \\
\text { jawab dikelas sudah } \\
\text { memadai }\end{array}$ & 3.44 & 4.36 & -0.92 \\
\hline 3 & $\begin{array}{l}\text { Suplemen bahan ajar } \\
\text { seperti modul, handout } \\
\text { dll. }\end{array}$ & 3.27 & 4.39 & -1.13 \\
\hline 4 & $\begin{array}{lr}\text { Dosen } & \text { selalu } \\
\text { mengembalikan hasil } \\
\text { ujian/tugas dengan diberi } \\
\text { nilai secara objektif }\end{array}$ & 3.16 & 4.34 & -1.19 \\
\hline 5 & $\begin{array}{l}\text { Dosen selalu tepat waktu } \\
\text { sesuai jadwal }\end{array}$ & 3.19 & 4.22 & 1.03 \\
\hline 6 & $\begin{array}{l}\text { Dosen mengampu mata } \\
\text { kuliah sesuai bidang } \\
\text { keahliannya }\end{array}$ & 3.73 & 4.53 & -0.80 \\
\hline 7 & $\begin{array}{l}\text { Dosen mengajar sesuai } \\
\text { dengan SAP }\end{array}$ & 3.58 & 4.45 & -0.88 \\
\hline 8 & $\begin{array}{l}\text { Staf akademik di jurusan } \\
\text { memiliki kemampuan } \\
\text { memadai dalam melayani } \\
\text { mahasiswa }\end{array}$ & 3.48 & 4.42 & -0.94 \\
\hline 9 & $\begin{array}{l}\text { Kualitas layanan staf } \\
\text { administrasi sudah baik }\end{array}$ & 3.38 & 4.48 & -1.11 \\
\hline \multicolumn{2}{|r|}{ Gap untuk dimensi tangible } & 3.08 & 4.48 & -1.40 \\
\hline
\end{tabular}

Berdasarkan tabel 2 tersebut tampak bahwa semua item dalam dimensi Reliability menunjukkan angka yang negative, dimana gap yang terendah -0.80 terdapat pada dosen pengampu mata kuliah sudah sesuai bidang keahliannya, dan gap tertinggi terjadi pada item dosen selalu mengembalikan hasil ujian/tugas dengan diberi nilai secara objektif yaitu 1.19. Secara keseluruhan dimensi Reliability memiliki gap yang negative sebesar -1.40, ini berarti apa yang dirasakan mahasiswa terkait dengan aspek keandalan dosen dan staf akademik masih lebih rendah dari yang mereka harapkan.

Tabel 3: Gap antara persepsi dan harapan pada dimensi Responsiveness (sikap tanggap)

\begin{tabular}{|c|c|c|c|c|}
\hline $\mathrm{N}$ & Aspek sikap tanggap & Persepsi & Harapan & Gap \\
\hline 0 & $\begin{array}{l}\text { pihak dosen dan staf } \\
\text { akademik }\end{array}$ & (P) & & $(\mathrm{P}-\mathrm{E})$ \\
\hline 1 & $\begin{array}{l}\text { PNJ menyediakan dosen } \\
\text { bimbingan konseling }\end{array}$ & 2.94 & 4.30 & -1.36 \\
\hline 2 & $\begin{array}{l}\text { PNJ menyediakan } \\
\text { beasiswa bagi yang tdk } \\
\text { mampu }\end{array}$ & 4.19 & 4.75 & -0.56 \\
\hline 3 & $\begin{array}{l}\text { PNJ membantu mhs yang } \\
\text { punya masalah akademik }\end{array}$ & 3.44 & 4.58 & -1.14 \\
\hline 4 & $\begin{array}{l}\text { Menyediakan waktu bagi } \\
\text { orang tua untuk konsultasi }\end{array}$ & 2.84 & 4.33 & -1.48 \\
\hline 5 & Memberikan & 3.19 & 4.44 & -1.25 \\
\hline
\end{tabular}




\begin{tabular}{lllll}
\hline pengobatan bagi yang & & & \\
sakit & $\begin{array}{l}\text { PNJ memberikan asuransi } \\
\text { kecelakaan bagi } \\
\text { mahasiswa } \\
\begin{array}{l}\text { Gap untuk dimensi } \\
\text { Responsiveness }\end{array}\end{array}$ & 3.11 & 4.45 & -1.34 \\
\hline
\end{tabular}

Berdasarkan tabel 3 tersebut tampak bahwa semua item dalam dimensi Responsiveness menunjukkan angka yang negative, dimana gap yang terendah -0.56 terdapat pada pertanyaan PNJ menyediakan beasiswa bagi yang tidak mampu, dan gap tertinggi terjadi pada item menyediakan waktu bagi orang tua mahasiswa untuk berkonsultasi yaitu -1.48; Secara keseluruhan dimensi Responsiveness memiliki gap yang negative sebesar -1.19, ini berarti apa yang dirasakan mahasiswa terkait dengan aspek sikap tanggap dari pihak administrasi akademik dan administrasi jurusan masih lebih rendah dari yang mereka harapkan.

Tabel 4: Gap antara persepsi dan harapan pada dimensi Assurance (perlakuan thd mahasiswa)

\begin{tabular}{|c|c|c|c|c|}
\hline $\begin{array}{l}\mathrm{N} \\
\mathrm{O}\end{array}$ & $\begin{array}{l}\text { Aspek perlakuan baik } \\
\text { pada mahasiswa }\end{array}$ & $\begin{array}{l}\text { Persepsi } \\
(\mathrm{P})\end{array}$ & $\begin{array}{c}\text { Harapan } \\
\text { (E) }\end{array}$ & $\begin{array}{l}\text { Gap } \\
(\mathrm{P}-\mathrm{E})\end{array}$ \\
\hline 1 & $\begin{array}{l}\text { Staf administrasi berlaku } \\
\text { ramah dan santun }\end{array}$ & 3.36 & 4.56 & -1.20 \\
\hline 2 & $\begin{array}{l}\text { Permasalahan mhs } \\
\text { ditangani oleh dosen PA }\end{array}$ & 3.28 & 4.55 & -1.27 \\
\hline 3 & $\begin{array}{l}\text { Permasalahan mhs } \\
\text { ditangani PNJ melalui } \\
\text { dosen bimbingan dan } \\
\text { konseling }\end{array}$ & 3.89 & 4.27 & -1.38 \\
\hline 4 & $\begin{array}{l}\text { Tugas dan hasil ujian } \\
\text { dikembalikan } \\
\text { mhs. }\end{array}$ & 3.08 & 4.39 & -1.31 \\
\hline 5 & $\begin{array}{ll}\text { Waktu } & \text { kuliah } \\
\text { dimanfaatkan oleh } & \text { dosen } \\
\text { scr efektif } & \end{array}$ & 3.52 & 4.41 & -0.89 \\
\hline 6 & $\begin{array}{l}\text { Penerapan sangsi yang } \\
\text { tegas kepada mahasiswa }\end{array}$ & 3.80 & 4.47 & -0.67 \\
\hline \multicolumn{2}{|c|}{ Gap untuk dimensi Assurance } & 3.32 & 4.44 & -1.12 \\
\hline
\end{tabular}

Berdasarkan tabel 4 tersebut tampak bahwa semua item dalam dimensi Assurance menunjukkan angka yang negative, dimana gap yang terendah -0.67 terdapat pada pertanyaan tentang penerapan sangsi yang tegas kepada mahasiswa yang melakukan pelanggaran, dan gap tertinggi terjadi pada item permasalahan/keluhan mahasiswa ditangani PNJ melalui dosen bimbingan dan konseling yaitu -1.38; Secara keseluruhan dimensi Assurance memiliki gap yang negative sebesar -1.12, ini berarti apa yang dirasakan mahasiswa terkait dengan aspek perlakuan pada mahasiswa dari pihak administrasi akademik dan administrasi jurusan masih lebih rendah dari yang mereka harapkan.

Tabel 5: Gap antara persepsi dan harapan pada dimensi Empathy (pemahaman thd kepentingan mahasiswa)

\begin{tabular}{clccc}
\hline $\mathrm{N}$ & $\begin{array}{l}\text { Aspek pemahaman pihak } \\
\text { PNJ terhadap kepentingan } \\
\text { mahasiswa }\end{array}$ & $\begin{array}{c}\text { Persepsi } \\
(\mathrm{P})\end{array}$ & $\begin{array}{c}\text { Harap } \\
\text { an } \\
(\mathrm{E})\end{array}$ & $\begin{array}{c}\text { Gap } \\
(\mathrm{P}-\mathrm{E})\end{array}$ \\
\hline 1 & $\begin{array}{l}\text { Kepedulian PNJ dalam } \\
\text { memahami kepentingan } \\
\text { dan kesulitan mahasiswa }\end{array}$ & 2.95 & 4.39 & -1.44 \\
2 & $\begin{array}{l}\text { Besarnya pembiayaan } \\
\text { kuliah (SPP) dibicarakan } \\
\text { dengan orang tua wali } \\
\text { mahasiswa }\end{array}$ & 2.98 & 4.27 & -1.28 \\
3 & $\begin{array}{l}\text { PNJ memonitor kemajuan } \\
\text { mahasiswa melalui dosen }\end{array}$ & 3.11 & 4.41 & -1.30 \\
$\begin{array}{l}\text { PA dan dosen bimbingan } \\
\text { dan konseling bersedia } \\
\text { Dosen } \\
\text { membantu mahasiswa } \\
\text { yang mengalami kesulitan } \\
\text { akademik atau mata } \\
\text { kuliah }\end{array}$ & & & \\
$\begin{array}{l}\text { Dosen bersikap kooperatif } \\
\text { dan terbuka thd } \\
\text { mahasiswa }\end{array}$ & 3.55 & 4.55 & -1.16 \\
$6 \begin{array}{l}\text { PNJ brusaha memahami } \\
\text { minat dan bakat } \\
\text { mahasiswa }\end{array}$ & 3.39 & 4.45 & -1.06 \\
Gap untuk dimensi Empathy & 3.23 & 4.44 & -1.21 \\
\hline
\end{tabular}

Berdasarkan tabel 5 tersebut tampak bahwa semua item dalam dimensi Empathy menunjukkan angka yang negative, dimana gap yang terendah -1.03 terdapat pada pertanyaan tentang sikap koopratif dan terbuka dosen terhadap mahasiswa, dan gap tertinggi terjadi pada item kepedulian PNJ dalam memahami kepentingan dan kesulitan mahasiswa yaitu 1.44; Secara keseluruhan dimensi Empathy memiliki gap yang negative sebesar -1.21, ini berarti apa yang dirasakan mahasiswa terkait dengan aspek pemahaman pihak PNJ terhadap kepentingan mahasiswa masih lebih rendah dari yang mereka harapkan.

Tabel 6: Gap antara persepsi dan harapan pada dimensi System Information (sistim informasi kemahasiswaan)

\begin{tabular}{|c|c|c|c|c|}
\hline $\begin{array}{l}\mathrm{N} \\
\mathrm{O}\end{array}$ & $\begin{array}{l}\text { Aspek pemahaman pihak } \\
\text { PNJ terhadap kepentingan } \\
\text { mahasiswa }\end{array}$ & $\begin{array}{l}\text { Persepsi } \\
\text { (P) }\end{array}$ & $\begin{array}{l}\text { Harap } \\
\text { an } \\
\text { (E) }\end{array}$ & $\begin{array}{l}\text { Gap } \\
\text { (P-E) }\end{array}$ \\
\hline 1 & $\begin{array}{lr}\text { PNJ menyediakan sistim } \\
\text { informasi perkuliahan } \\
\text { dalam bentuk } & \text { buku } \\
\text { panduan } & \text { sistim } \\
\text { perkuliahan } & \end{array}$ & 3.14 & 4.39 & -1.25 \\
\hline 2 & $\begin{array}{l}\text { PNJ menyediakan sistim } \\
\text { informasi akademik dan } \\
\text { non akademik secara } \\
\text { daring di web PNJ }\end{array}$ & 3.66 & 4.58 & -0.92 \\
\hline 3 & 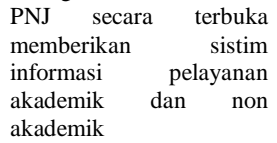 & 3.48 & 4.48 & -1.0 \\
\hline 4 & $\begin{array}{lr}\text { PNJ membuka layanan } \\
\text { pengaduan } & \text { bagi }\end{array}$ & 3.05 & 4.53 & -1.48 \\
\hline
\end{tabular}




\begin{tabular}{|c|c|c|c|c|}
\hline \multirow[b]{2}{*}{5} & $\begin{array}{l}\text { mahasiswa yang memiliki } \\
\text { permasalahan }\end{array}$ & & & \\
\hline & $\begin{array}{l}\text { PNJ selalu berusaha } \\
\text { memberikan respon } \\
\text { positif terhadap setiap } \\
\text { pengaduan mahasiswa }\end{array}$ & 3.11 & 4.47 & -1.36 \\
\hline 6 & $\begin{array}{l}\text { PNJ berusaha secara } \\
\text { transparan dalam } \\
\text { menjelaskan penggunaan } \\
\text { dana kemahasiswaan }\end{array}$ & 2.29 & 4.47 & -1.58 \\
\hline & $\begin{array}{l}\text { ap untuk dimensi System } \\
\text { Information }\end{array}$ & 3.22 & 4.49 & -1.27 \\
\hline
\end{tabular}

Berdasarkan tabel 6 tersebut tampak bahwa semua item dalam dimensi System Information menunjukkan angka yang negative, dimana gap yang terendah -0.92. terdapat pada pertanyaan tentang PNJ menyediakan sistim informasi akademik dan non akademik secara daring di web, dan gap tertinggi terjadi pada item pertanyaan PNJ berusaha secara transparan dalam menjelaskan penggunaan dana kemahasiswaan yaitu -1.58; Secara keseluruhan dimensi System Information memiliki gap yang negative sebesar -1.27 , ini berarti apa yang dirasakan mahasiswa terkait dengan aspek sistim informasi kemahasiswaan masih lebih rendah dari yang mereka harapkan.

Angka gap dalam analisa servqual yang digunakan dalam penelitian ini dapat diartikan sebagai selisih antara nilai persepsi yang dirasakan (perceiped) dan nilai harapan (expectation) atau dengan kata lain selisih antara nilai yang dipersepsikan oleh mahasiswa dengan nilai yang diharapkannya tentang pelayanan akademik dan kemahasiswaan di PNJ. Angka gap yang positif menunjukkan bahwa tingkat kepuasan mahasiswa sudah melampaui apa yang diharapkannya sehingga dalam hal seperti ini pihak PNJ tidak perlu meningkatkan kualitas layanan kemahasiswaanya tapi cukup hanya mempertahankannya. Sebaliknya apabila angka gap bernilai negative, maka berarti tingkat kepuasan mahasiswa masih berada dibawah apa yang diharapkannya, dalam hal seperti ini pihak PNJ harus meningkatkan kualitas layanannya karena belum mampu untuk memberikan pelayanan sesuai dengan apa yang diharapkan oleh mahasiswa.
Hasil analisa data menunjukkan bahwa angka gap servqual untuk semua dimensi yang menjadi objek penelitian menunjukkan angka negative seperti yang ditunjukkan pada tabel 1 sampai dengan tabel 6, dan hasil ini dapat dijelaskan sebagai berikut:

1) Pada aspek tangible yang terkait dengan kebersihan, kerapihan, kenyamanan dan kelengkapan ruang perkuliahan, ruang perpustakaan yang nyaman dan tersedianya buku referensi yang memadai, laboratorium komputer, laboratorium bahasa, bengkel yang sesuai kebutuhan keilmuan, sampai dengan kamar kecil dan tempat ibadah semua menunjukkan angka gap yang negative. Artinya dalam aspek ini tingkat kepuasan mahasiswa masih dibawah dari apa yang diharapkannya. Dengan kata lain PNJ harus melakukan perbaikan secara fisik dibidang sarana prasarana pendidikan, seperti ruang kelas yang nyaman dan lengkap, perpustakaan yang nyaman dan lengkap, laboratorium yang relevan dengan bidang keilmuan sampai dengan sarana tempat ibadah;

2) Pada aspek Reliability yang terkait dengan keandalan dosen sebagai ujung tombak lembaga pendidikan dan tenaga kependidikan atau staf akademik yang melayani kepentingan mahasiswa dalam banyak hal, menunjukkan gap yang negative. Kepuasan mahasiswa dalam hal ini secara rata-rata masih dibawah ekspektasi mereka, ini berarti bahwa PNJ harus berusaha untuk meningkatkan kinerja dosennya melalui berbagai macam cara. Selain melalui recruitment tenaga dosen baru yang lebih selektif, untuk tenaga yang sudah ada perlu diberikan berbagai macam pelatihan yang dapat meningkatkan kompetensi dibidangnya masing-masing. Pemberian penghargaan (reward) dan penerapan hukuman (punishment) kepada dosen merupakan salah satu cara untuk 
meningkatkan kinerja mereka dalam memberikan pelayanan kepada mahasiswa. Untuk tenaga kependidikan dapat ditingkatkan kinerjanya melalui pelatihan terkait dengan pelayanan yang prima dengan mendatangkan prakatisi dibidang terkait.

3) Aspek Responsiveness yang terkait dengan sikap tanggap dari pihak PNJ dalam melayani mahasiswa melalui bimbingan dan konseling, pemberian berbagai macam beasiswa, konsultasi mahasiswa dan orang tua/wali, bantuan pengobatan sampai dengan asuransi kecelakaan mahasiswa memiliki angka gap yang negative. Dalam hal ini tingkat kepuasan mahasiswa masih lebih rendah dari apa yang mereka harapkan. Maka dari itu PNJ harus berusaha mengakomodir kepentingan mahasiswa dengan meningkatkan pelayanan yang sudah ada dan menyediakan pelayanan yang belum tersedia seperti ruang konsultasi untuk orang tua dan asuransi kecelakaan bagi mahasiswa.

4) Aspek Assurance yang terkait dengan memperlakukan mahasiswa secara baik mulai dari pelayanan keadministrasian, pelayanan kesehatan, pelayanan bidang akademik bagi mereka yang mengalami masalah-masalah akademik, pelayanan oleh dosen terkait tugas dan pemberian nilai secara objektif sampai dengan penerapan sangsi bagi mahasiswa yang melakukan pelanggaran belum memberikan kepuasan yang maksimal. Oleh karenanya PNJ masih harus bekerja keras untuk memperbaiki aspek ini sehingga dapat memberikan perlakuan yang lebih baik, sehingga tidak ada lagi keluhan dari mahasiswa dalam aspek assurance ini.

5) Pada aspek Empathy atau yang terkait dengan pemahaman manajemen PNJ terhadap kepentingan-kepentingan mahasiswa gapnya masih negative. Ini menunjukkan bahwa mahasiswa merasa bahwa kepentingan mereka masih dibawah ekspektasi yang mereka inginkan. Dalam hal ini jajaran pimpinan dilingkungan PNJ harus lebih peka memahami berbagai hal menyangkut kesulitan yang dihadapi oleh mahasiswa baik secara akademik ataupun secara finansial dan dalam hal pengembangan bakat dan minat mahasiswa. Jajaran pimpinan PNJ dapat meningkatkan aspek empathy dengan cara semakin sering melakukan komunikasi yang baik dengan pihak mahasiswa dalam berbagai kesempatan.

6) Sistim informasi mahasiswa (academic information system) dalam sebuah perguruan tinggi sangat dibutuhkan dalam rangka memberikan pemahaman mahasiswa terhadap system perkuliahan, keterbukaan termasuk dalam penggunaan dana SPP mahasiswa. Sistem informasi mahasiswa saat ini harus dapat diakses langsung oleh mahasiswa secara daring (on-line) sehingga mahasiswa akan dengan mudah mengakses informasi apapun yang mereka butuhkan melalui web institusi. Selama ini system informasi akademik secara daring sudah disediakan oleh PNJ yang disebut dengan unisys system, akan tetapi sistim ini belum dimanfaatkan secara optimal oleh pihak internal PNJ termasuk para dosen belum memasukkan nilai UTS dan nilai UAS ke dalam Unisys. Dalam kaitan ini perlu adanya sosialisasi yang lebih serius dan berkelanjutan dari pusat layanan informasi PNJ, agar optimalisasi pemanfaatan Unisys dapat terujud.

Secara keseluruhan (aggregate) dari enam dimensi pelayanan bidang akademik dan kemahasiswaan yang diberikan PNJ menunjukkan bahwa gap antara yang dirasakan mahasiswa dengan harapan mereka menunjukkan angka yang negative. Ini menunjukkan bahwa tingkat 
kepuasan dan kualitas pelayanan bidang akademik dan kemahasiswaan di PNJ masih lebih rendah dari apa yang mereka inginkan. Oleh karenanya PNJ harus terus berbenah diri dalam semua aspek atau dimensi yang menyangkut pelayanan bidang akademik dan kemahasiswaan, agar gap antara yang dirasakan oleh mahasiswa dengan apa yang diharapkan menjadi nol atau tidak ada.

\section{KESIMPULAN DAN SARAN}

Berdasarkan hasil analisa servqual dapat disimpulkan bahwa tingkat kepuasan dan kualitas pelayanan bidang akademik dan kemahasiswaan yang dirasakan oleh mahasiswa secara umum masih lebih rendah dari yang mereka harapkan. Oleh kerena itu agar gap antara apa yang dirasakan mahasiswa dengan harapan mereka menjadi nol, maka PNJ harus melakukan perbaikan pelayanan bidang akademik dan kemahasiswaan mulai dari dimensi tangible (aspek fisik), dimensi reliability (aspek keandalan), dimensi responsivness (aspek sikap tanggap), dimensi assurance (aspek perlakuan kepada mahasiswa), dimensi empathy (aspek memahami kepentingan mahasiswa) dan dimensi information system (sistim informasi kemahasiswaan).

\section{UCAPAN TERIMAKASIH}

Dalam kesempatan ini penulis ingin menghaturkan terimakasih yang sebesarbesarnya khususnya kepada pihak institusi Politeknik Negeri Jakarta yang sudah memberikan pendanaan sehingga memungkinkan terselenggaranya kegiatan penelitian ini. Selanjutnya terimaksih juga kepada P3M PNJ yang menyelenggarakan program penelitian skim bidang ilmu dan pengembangan institusi (BIL) dan kepada semua pihak yang turut berkontribusi terhadap penelitian ini.

\section{DAFTAR PUSTAKA}

Engel, A. A. (1990). Consumer Behavior. Chicago: The Dryden Press.

Hasibuan, Chalis Fajri, 2017. Identifikasi Tingkat Kualitas Pelayanan Jasa Pendidikan Dengan menggunakan Servqual di Fakultas Teknik Universitas $\mathrm{X}$, Jurnal Spektrum Industri Volume 11, No.1 Tahun 2017

Kotler. (2005). Manajemen Pemasaran. Jakarta: Salemba Empat.

Reina. (Mei 2012). Faktor-Faktor Yang Mempengaruhi Jepuasan Mahasiswa Pada Universitas Bina Nusantara. Binus Business Review Vol 3 No 1 , $563-572$.

Schnaars, S. P. (1991). Marketing Strategy: A Customer Driven Approach. New York: The Free Press.

Sopiah, E. M. (2013). Perilaku Konsumen. Jogjakarta: Andi

Sutrisno, C. F. (2017). Identifikasi Tingkat Kualitas Pelayanan Jasa Pendidikan Dengan Menggunakan SerQual . Spektrum Industri Vol 15 No 1,19 - 26.

Tjiptono, F. (1994). Analisis Kepuasan Pelanggan Sebagai Dasar Penyusunan Strategi Pemasaran Defensif Pada Novell Computer Yogyakarta. Yogyakarta: FE UGM.

Zeithaml, M. J. (2005). Customer Contributions and Roles in Service Delivery. North Carolina: University of North Carolina. 